$\begin{array}{ccc}\text { Tersedia online di: http://ejournal-balitbang.kkp.go.id/index.php/jppi } & \text { JURNAL } \\ \text { e-mail:jppi.puslitbangkan@ gmail.com } & \text { PENELTIAN } \\ \text { PERIKANAN } & \text { INDONESIA } \\ \text { JURNALPENELITIANPERIKANANINDONESIA } & \text { Volume 23 Nomor 3 September 2017 } \\ \text { e-ISSN: 2502-6542 } & \\ \text { Nomor Akreditasi: 653/AU3/P2MI-LIPI/07/2015 }\end{array}$

\title{
PENCATATAN KEDUA DAN BEBERAPA ASPEK BIOLOGI LOBSTER BATIK MERAH (Panulirus longipes femoristriga Von Martens, 1872) YANG DITANGKAP DI TELUK SEPI, LOMBOK BARAT
}

\author{
SECOND RECORD AND SOME BIOLOGICAL ASPECTS OF \\ Panulirus longipes femoristriga Von Martens, 1872 CAUGHT \\ IN SEPI BAY, WEST LOMBOK
}

\author{
Amula Nurfiarini dan Sri Endah Purnamaningtyas ${ }^{1}$ \\ 'Balai Riset Pemulihan Sumber Daya Ikan, Jl. Cilalawi No. 1, Jatiluhur, Purwakarta, Jawa Barat 41152, \\ Indonesia \\ Teregistrasi I tanggal: 29 Mei 2017; Diterima setelah perbaikan tanggal: 11 Agustus 2017; \\ Disetujui terbit tanggal: 16 Agustus 2017
}

\begin{abstract}
ABSTRAK
Panulirus longipes femoristriga atau lobster batik merah merupakan salah satu jenis tropical spiny lobster dari Famili Palinuridae yang jarang ditemukan di Perairan Indonesia. Untuk itu penting dilakukan pengamatan aspek biologi lobster batik merah ini dan sejarah penemuannya di perairan Indonesia. Penelitian dilakukan dengan menggunakan pendekatan metode percobaan penangkapan dengan tangan dan bantuan kompresor. Beberapa analisis yang dilakukan antara lain analisis komposisi, kelas ukuran, kebiasaan makanan, analisis tingkat kematangan gonad dan fekunditas. Hasil penelitian menunjukkan bahwa berdasarkan sejarah ditemukan, lobster batik merah ( $P$. I. femoristriga) merupakan tropical spiny lobster dari kelompok Palinuridae dan merupakan salah satu sub varian dari lobster batik ( $P$. longipes). Jenis ini tercatat ditemukan di perairan Lombok sebagai lokasi ke empat di Indonesia setelah Perairan Sulawesi, Papua Barat, dan Ambon. Komposisinya di perairan menempati nilai prosentase bobot dan jumlah masing masing dalam kisaran 11,26-12,03 \% dan 21,28- 22,5\%, berada di urutan ke empat setelah lobster batu, bambu dan batik. Struktur ukuran hasil tangkapan didominasi ukuran larang tangkap. Kebiasaan makanan dari lobster batik merah terdiri atas kelompok moluska: jenis gastropoda dan bivalvia, krustasea jenis udang udangan dan kepiting serta makrofita. Fekunditas bekisar antara $8.332-66.076$ butir dengan diameter telur berkisar antara 0,45-0,79 mm. Panjang karapas dan bobot pada saat pertama kali matang gonad masing-masing adalah $3,8-4,7 \mathrm{~cm}(4.3 \mathrm{~cm})$ dan $66,12-106,45 \mathrm{gr}$. (rata rata $87,58 \mathrm{gr}$ ).
\end{abstract}

Kata Kunci: Panulirus longipes femoristriga; biologi; kebiasaan makan; Lombok Barat

\begin{abstract}
Panulirus longipes femoristriga or red batik lobster (white-whiskered coral crayfish) is one type of tropical spiny lobster from the Family of Palinuridae that is rarely found in Indonesian waters. It is important to observe the biological aspects of this red batik lobster and the history of its discovery in Indonesian waters. The research was carried out using a hand-held method of and compressor equipment. Several analyzes were performed, among others, composition analysis, class size, food habits, maturity level analysis of gonad and fecundity. The results showed that based on the history of the red batik lobster (P. I. femoristriga) tropical spiny lobster of one of sub variants of batik lobster (P. longipes). This species recorded is found in the waters of Lombok as the fourth location in Indonesia after the waters of Sulawesi, West Papua, and Ambon. Its composition occupies precentage value of weight and number of each in the range of 11.26 to $12.03 \%$ and 21.28 to $22.5 \%$ respectively, ranked as fourth after rock, bamboo and batik lobsters. The size of the catch is dominated by the size of the ban. The food habit of red batik lobsters of mollusks: gastropods and bivalves, crustaceans (shrimps) and crabs as well as macrophytes. Fecundity ranged between
\end{abstract}


8,332 - 66,076 eggs, with diameter ranging from 0.45 to $0.79 \mathrm{~mm}$. The carapace length and weight at the first mature gonad ranged between $3.8-4.7 \mathrm{~cm}(4.3 \mathrm{~cm}$ ) and $66.12-106.45 \mathrm{gr}$ (average $87.58 \mathrm{gr})$, respectively.

\section{Keywords: Panulirus longipes femoristriga; biological aspect; feeding habits; West Lombok}

\section{PENDAHULUAN}

Lobster merupakan salah satu komoditas perikanan unggulan pada pasar domestik maupun ekspor. Data Direktorat Jenderal Perikanan Tangkap (2015) menunjukkan produksi lobster Indonesia selama periode 2005-2014 cukup fluktuatif cenderung meningkat dari 6,65 ton pada 2005 hingga mencapai 16,482 ton pada 2013 , namun kemudian menurun hingga sekitar 4 ton, mencapai angka produksi 10,086 ton pada 2014. Jumlah tersebut setara dengan $72 \%$ dari target produksi yang terpenuhi.

Di Indonesia tercatat telah ditemukan tujuh jenis spiny lobster (Tewfik et al., 2009; Phillips, 2006; Chan et al., 2013; Wardiatno et al., 2016), atau 7,23\% dari total spiny lobster di seluruh dunia (Williams et. al., 1986; Chan, 1998). Enam jenis diantaranya termasuk dalam kelompok tropical spiny lobster dari Famili Palinuridae genus Panulirus yaitu Panulirus homarus (Lobster Pasir), P. ornatus (Lobster Mutiara), P. longipes (Lobster Batik), P. versicolor (Lobster Bambu), P. polyphagus (Lobster Pakistan/Lumpur) dan $P$. penicillatus (Lobster batu), dan satu jenis dari kelompok deep-sea spiny lobster dari genus Puerulus yaitu Puerulus mesodontus (Wardiatno et al., 2016). Ke enam jenis dari kelompok tropical spiny lobster tersebut mempunyai distribusi yang sangat luas yakni kawasan Indo-Pacific (Holthius, 1991). Pada beberapa spesies khususnya P. Homarus dan P. Longipes mempunyai banyak sub spesies (Lavery et al., 2014), dua diantaranya ditemukan di Perairan Indonesia yakni $P$. homarus homarus dan $P$. longipes femoristriga.

$P$. longipes femoristriga merupakan salah satu varian/sub spesies dari lobster batik. Di perairan Indonesia, jenis ini tercatat baru ditemukan di empat lokasi, yakni Perairan Sulawesi dan Papua Barat (Wahyudin, 2016), Ambon (Holtuis, 1991; Chan \& Chu, 1996), serta pesisir Pulau Lombok (Kalih, 2012). Oleh sebab itu, informasi yang mengungkap mengenai karakteristik dan keberadaannya baik di perairan maupun dalam komunitas Panulirus masih sangat minim. Penelitian ini bertujuan untuk mengetahui status sejarah penemuan dari lobster batik merah (Panulirus longipes femoristriga), beberapa aspek biologi (yang terdiri dari morfologi, kebiasaan makan,fekunditas), dan status keberadaan di perairan maupun dalam komunitas Panulirus.

\section{BAHAN DAN METODE}

Penelitian dilakukan selama tahun 2016 di perairan sekitar Teluk Sepi, Lombok Barat (Gambar 1). Data yang dikumpulkan meliputi data primer dan data sekunder. Data primer diperoleh menggunakan metode survei dengan pendekatan percobaan penangkapan menggunakan kebiasaan penangkapan yang digunakan nelayan setempat yakni melalui penyelaman oleh satu kelompok penyelam terdiri dari lima orang dengan menggunakan kompresor. Data tersebut meliputi kelimpahan dan komposisi jenis, struktur ukuran panjang karapas dan bobot, kebiasaan makan dan karateristik reproduksi.

Pengamatan terhadap kebiasaan makan lobster batik merah dengan total sampel ( $\mathrm{N}=12$ ekor) yakni sebanyak lima ekor pada Mei, dan tujuh ekor pada Oktober. Pengambilan data kebiasaan makan lobster dilakukan dengan cara mengamati isi lambung yang diambil dengan membedah/menggunting karapas kepala, sebelumnya dilakukan pencatatan panjang karapas dan berat lobster pada blanko yang telah disediakan. Sampel lambung lobster dimasukkan ke dalam plastik yang telah diberi label dan diawetkan dengan formalin $5 \%$, sedangkan spesimen diawetkan dalam alkohol $96 \%$ dan disimpan di Laboratorium Sumberdaya Ikan BP2KSI. Data sekunder dikumpulkan melalui desk study dari beberapa literatur terkait penelitian khususnya mengenai sejarah dan taksonomi. 


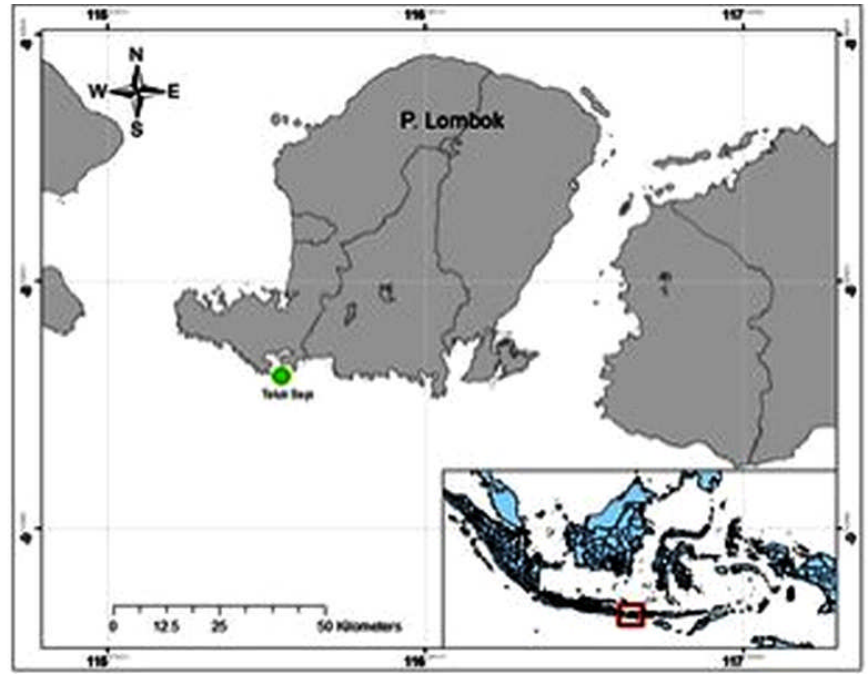

Gambar 1. Lokasi Penelitian.

Figure 1. Site of research.

Selanjutnya data dianalisis dengan menggunakan beberapa pendekatan yakni deskripsi dan taksonomi merujuk pada Chan \& Chu (1996); Chan, (1998) dan Chan \& Ng (2001). Kebiasaan makan menggunakan Index of Preponderance atau indeks bagian terbesar (Natarajan \& Jhingran, 1961), dengan rumus:

$I i=\left[\frac{(V i-O i)}{\sum_{i}^{n}(V i . O i)}\right] X 100 \%$

dimana,

$\mathrm{li}=$ Indeks bagian terbesar (index of preponderance)

$V_{i}=$ Persentase volume makanan lobster jenis kei

$O_{i}=$ Persentase frekuensi kejadian makanan jenis ke-i

$\mathrm{n}=$ Jumlah organisme makanan lobster $(\mathrm{i}=$ $1,2,3, \ldots . n)$
Tingkat kematangan gonad mengikuti 4 tahap yang merujuk pada Berry (1971), yakni; immature, development, ripe dan spent (pada lobster betina), dan absent, recently mated, used dan old (pada lobster jantan) (Tabel 1). Fekunditas ditentukan menggunakan gabungan dari metode gravimetrik dan metode sub contoh (Bagenal \& Braum, 1978; Effendie, 1979) dengan rumus:

$F=\frac{G}{Q} X$

dimana,

$\mathrm{F}=$ Fekunditas (butir)

$\mathrm{X}=$ Jumlah telur dalam sebagian kecil dari sampel gonad (butir)

$G=$ Berat seluruh sampel gonad (gram)

$Q=$ Berat sebagian kecil dari sampel sampel gonad (gram)

Tabel 1. Tingkat perkembangan ovarium dan masa sperma pada lobster

Table 1. Levels of ovarian development and sperm duration in lobsters

\begin{tabular}{|c|c|c|c|}
\hline $\begin{array}{l}\text { Komponen/ } \\
\text { Component }\end{array}$ & $\begin{array}{l}\text { Tahap/ } \\
\text { Phase }\end{array}$ & $\begin{array}{l}\text { Klasifikasi// } \\
\text { Classification }\end{array}$ & $\begin{array}{l}\text { Keterangan/ } \\
\text { Explanation }\end{array}$ \\
\hline \multirow[t]{2}{*}{$\begin{array}{l}\text { Perkembangan } \\
\text { ovarium }\end{array}$} & $\begin{array}{ll}1 \\
2\end{array}$ & $\begin{array}{l}\text { Immature } \\
\text { Developing }\end{array}$ & $\begin{array}{l}\text { Ovarium putih ( } 2 \mathrm{~g} \text { atau kurang), rata dorsoventrally. } \\
\text { Ovarium merah muda sampai oranye pudar/pucat (10- } \\
20 \mathrm{~g} \text { ), terasa membesar }\end{array}$ \\
\hline & $\begin{array}{l}3 \\
4\end{array}$ & $\begin{array}{l}\text { Ripe } \\
\text { Spent }\end{array}$ & $\begin{array}{l}\text { Ovarium oranye terang ke merah, membesar }(30-80 \mathrm{~g}) \text {. } \\
\text { Ovarium putih, kuning atau merah muda pucat, } \\
\text { ovarium sering sedikit lebih besar dari tahap } 3 \text { yang } \\
\text { dipertahankan secara ekstrim pada cuping ovarium. } \\
\text { Secara makroskopis sering dibedakan dari tahap } 1 .\end{array}$ \\
\hline \multirow[t]{3}{*}{$\begin{array}{l}\text { Perkembangan } \\
\text { masa sperma }\end{array}$} & $\begin{array}{l}0 \\
1\end{array}$ & $\begin{array}{l}\text { Absent } \\
\text { Recently } \\
\text { mated }\end{array}$ & $\begin{array}{l}\text { Massa sperma mempertahankan matriks pelindung di } \\
\text { atasnya dalamkondisiunscraped. }\end{array}$ \\
\hline & 2 & Used & $\begin{array}{l}\text { Matriks pelindung atasnya telah hilang, mengekspos } \\
\text { sperma pokok, dan memungkinkan pembuahan terjadi }\end{array}$ \\
\hline & 3 & Old & Massa spermasangat terfragmentasi/terbagi \\
\hline
\end{tabular}




\section{HASIL DAN BAHASAN \\ Hasil}

\section{Sejarah dan Deskripsi Taksonomi}

Pada awal pencatatannya, lobster batik merah (Panulirus longipes femoristriga) diklasifikasikan sebagai Panulirus femoristriga (Von Martens, 1872), sebuah spesies tersendiri dalam kelompok Panulirus. Selanjutnya dimasukkan ke dalam jenis $P$. longipes (Milne Edwards, 1868) sebagai subspesies dengan nama $P$. longipes femoristriga. Dalam perkembangannya Chan \& Chu (1996) melalui analisis morfologi dan allozyme menunjukkan bahwa sebenarnya ada dua bentuk samar dari $P$. longipes femoristriga dan serupa dengan Panulirus albiflagellum Chan \& Chu 1996, kemudian pada 2001 melalui kajian haplotype, Chan \& Nge berhasil mengungkapkan bahwa $P$. albiflagellum adalah sejenis dengan haplotype $P$. femoristriga, dan $P$. Longipes femoristriga sejenis dengan $P$. longipes bispinosus Borradaile, 1899 (Ravago \& Juinio-Menez, 2002; Chow et al., 2006) (Gambar 2). Berdasarkan sejarah tersebut, maka deskripsi taksonomi dari lobster batik merah adalah sebagai berikut:

\section{Kingdom : ANIMALIA \\ Philum : CRUSTACEA}
Kelas
MALACOSTRA
Ordo
DECAPODA
Sub ordo : ACHELATA Scholtz et Richter, 1995
Family : PANULIRUDEAE Latreille, 1802
Genus : Panulirus White, 1847
Spesies : Panulirus longipes A. Milne Edwards, 1868

Sub Spesies : Panulirus longipes femoristriga(Von Martens, 1872)

Kesamaan : Panulirus femoristriga Von Martens, 1872; Panulirus longipes ssp. femoristriga von Martens, 1872; $P$. longipes bispinosus Borradaile, 1899; dan Panulirus albiflagellum Chan \& Chu, 1996

Di Indonesia, jenis ini untuk pertama kalinya ditemukan di wilayah perairan Ambon dan Papua pada 1996 (Chan, 1996), dan ditemukan kembali di kawasan yang sama yakni sekitar Seram pada September 2016 (Wahyudin et al., 2016). Sedangkan di perairan Pesisir Lombok, untuk pertama kalinya jenis ini berhasil ditemukan pada 2012 dalam penelitian yang dilakukan oleh Kalih. Penemuannya tersebar pada beberapa perairan sekitar Pulau Lombok diantaranya Teluk Sepi, Gili Matra, Serenting, Sekotong, dan Sukadana. Selanjutnya tercatat ditemukan kembali untuk yang kedua kali pada 2016.

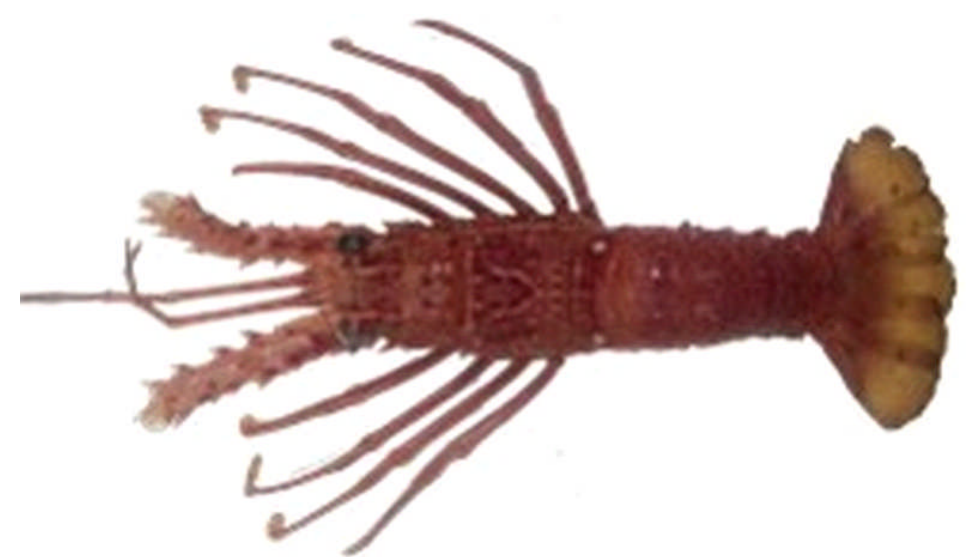

Gambar 2. Spesimen lobster batik merah P. Iongipes femoristriga Von Morten, 1872.

Figure 2. Specimen of P. longipes femoristriga Von Morten, 1872.

\section{Morfologi Panulirus longipes femoristriga}

Secara umum kelompok udang udangan memiliki morfologi yang terbagi dalam tiga bagian utama yakni kepala (karapas), perut, dan ekor. Karapas lobster berbentuk bulat dan berduri, tidak memiliki rostrum, margin anterior dilengkapi dengan duri tak beraturan; tinggi tanduk depan sekitar 2,5 kali tinggi mata; daerah tengah di belakang tanduk depan memiliki tiga buah duri umumnya membentuk garis memanjang (Gambar 3a); alur serviks jelas lebih lebar daripada alur marjinal posterior (Gambar 3b). Antena dengan flagella lebih panjang dari pada peduncle; pelat antennular pada dasar antena membawa satu pasang duri inti yang terpilah dengan baik dan beberapa spinulus yang tersebar (Gambar 3b). Permukaan ventral terdiri atas dua segmen anterior distal, masing-masing dengan deretan dua kelopak berukuran sama (Gambar 3c). Pada sternum torak terdapat dua tonjolan sub median yang kuat (Gambar 3d). Segmen perut dengan alur melintang lengkap bergabung dengan alur pleura; pleura abdomen hanya dengan segmen kedua yang terkadang mengandung spinules (Gambar $3 \mathrm{e}$ ). 


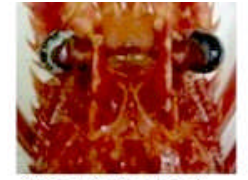

Atas(above)

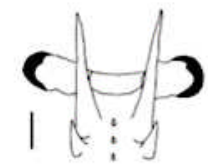

Bawah (under)
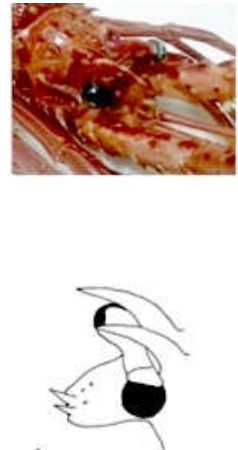

(a) antennular plate
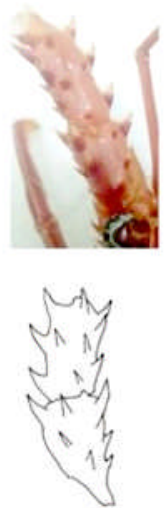

(c)Antennal peduncle
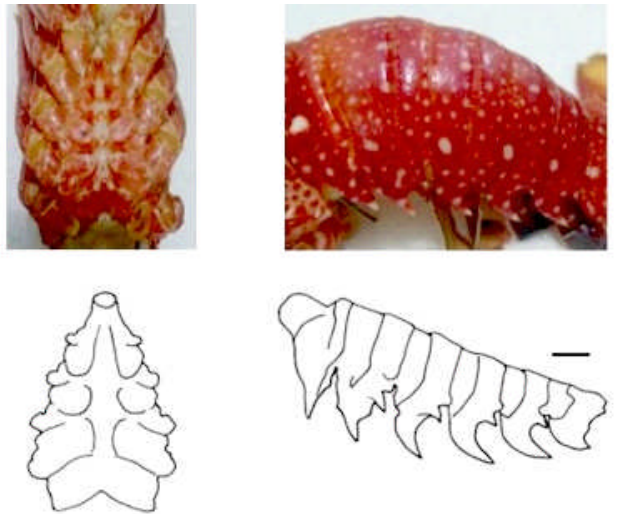

(d) Thoracic sternum

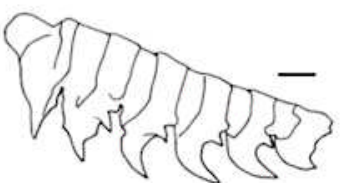

(e) Abdomen anterdorsal

Gambar 3. Panulirus longipes femoristriga dari Teluk Sepi, Lombok Barat (atas:Nurfiarini, 2016; bawah: Wahyudin et al, 2016).

Figure 3. Panulirus longipes femoristriga from Sepi Bay, West Lombok (above: Nurfiarini, 2016; below: Wahyudin et al., 2016).

\section{Proporsi Kelimpahan dan Komposisi dalam} Komunitas Panulirus

Hasil pengamatan menunjukkan bahwa keanekaragaman jenis lobster di lokasi penelitian teridentifikasi sebanyak enam jenis lobster dari famili Palinurideae yakni Panulirus homarus (Lobster Pasir), $P$. ornatus (mutiara), P. longipes (batik), P. versicolor (bambu), P. penicillatus (batu) dan P. I. femoristriga (batik merah) yang merupakan sub spesies dari lobster batik.

Komposisi hasil percobaan penangkapan pada Mei maupun Oktober dari total sampel (N) 87 ekor, didominasi oleh jenis batu, baik dari bobot maupun jumlah, dimana bobot pada masing masing bulan pengamatan $41,01 \%$ dan $31,26 \%$, dan proporsi jumlah $36,17 \%$ dan $30,00 \%$. Selanjutnya secara berurutan adalah bambu, batik, batik merah, mutiara dan pasir (Gambar 4, 5).

Lobster batik merah menempati komposisi bobot dan jumlah masing masing dalam kisaran 11,26-12,03 $\%$ dan 21,28- 22,5 \%. Komposisi tersebut tidak berbeda jauh dengan komposisi lobster batik, sehingga dapat diartikan bahwa kedua jenis ini memanfaatkan ruang yang serupa dalam komunitasnya.

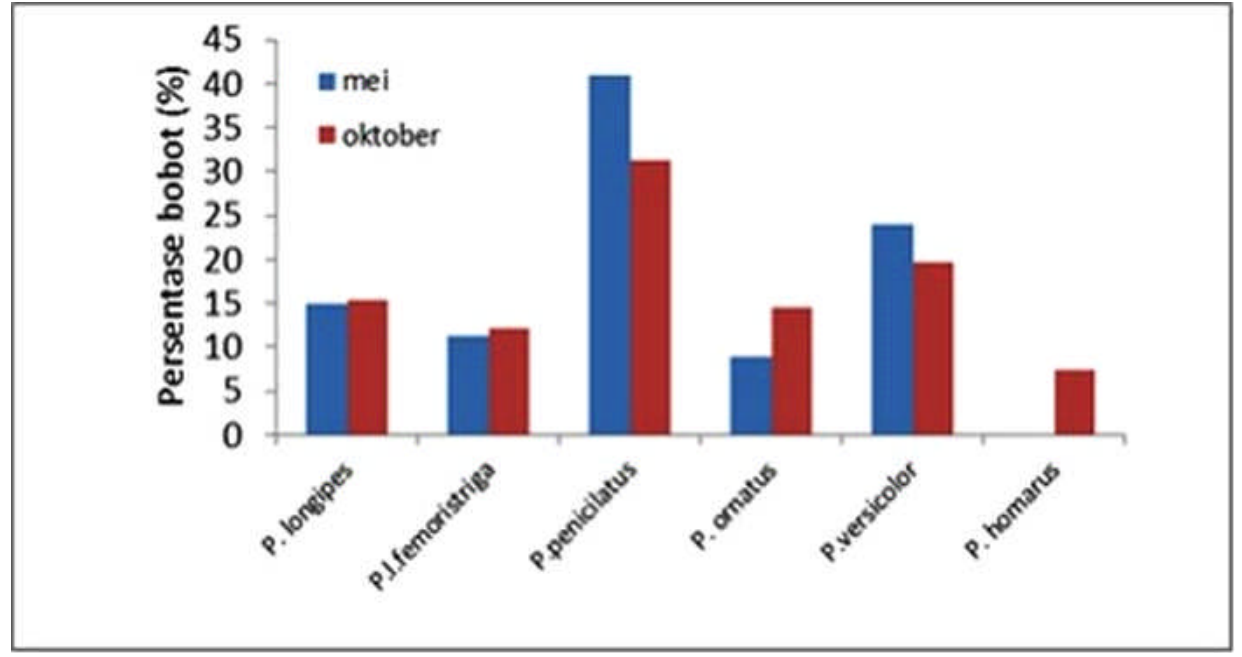

Gambar 4. Komposisi relatif (\%) tangkapan lobster berdasarkan bobot.

Figure 4. Relative composition (\%) of lobster catch based on weight. 


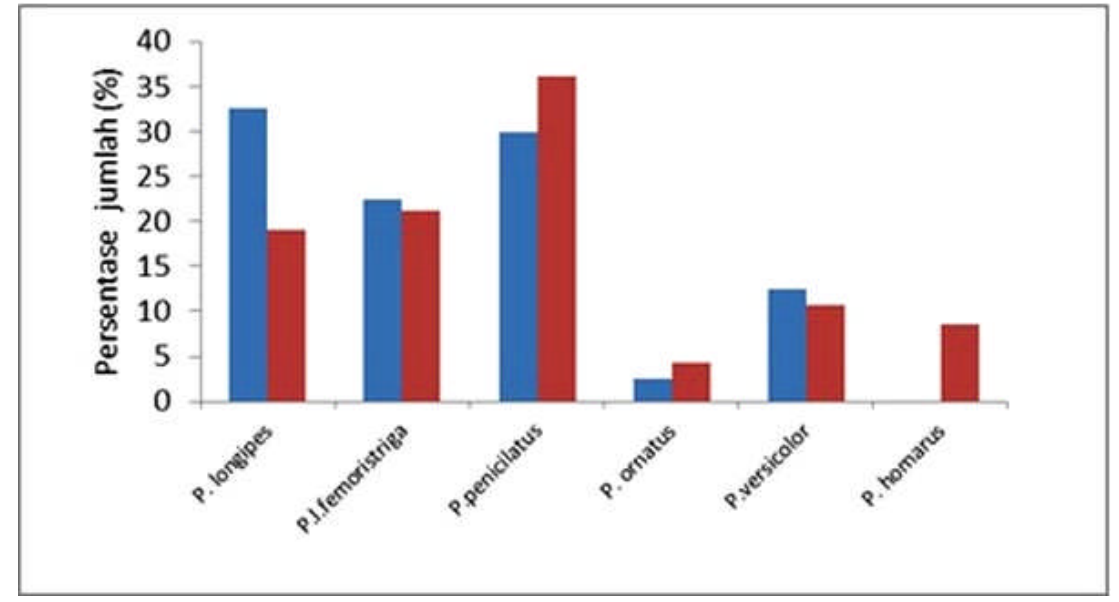

Gambar 5. Komposisi relatif (\%) tangkapan lobster berdasarkan jumlah.

Figure 5. Relative composition (\%) of lobster catch based on number.

\section{Sebaran Ukuran Panjang Karapas dan Bobot}

Lobster yang tertangkap dalam penelitian ini berada pada kisaran panjang karapas antara 3,15$11,6 \mathrm{~mm}$ (rata rata $6,8 \mathrm{~mm}$ ) dan kisaran bobot antara 40,17-1.250 gr (rata rata 121,48). Sedangkan pada jenis batik merah, kisaran panjang karapas yang tertangkap antara 3,8 $-5,9 \mathrm{~mm}$ (rata rata 4,89 $\mathrm{mm}$ ) dan kisaran bobot antara 40,17-170,21 gr (rata rata $120,18 \mathrm{gr}$ ) (Lampiran 1). Keadaan ini menunjukkan bahwa hasil tangkapan di Teluk Sepi, baik keseluruhan jenis maupun pada jenis batik merah didominasi oleh ukuran panjang karapas $<80 \mathrm{~mm}$, yakni ukuran larang tangkap yang disyaratkan dalam PerMen-KP No 1 Tahun 2015. Demikian juga pada kategori bobot, hasil tangkapan didominasi oleh ukuran bobot $<200 \mathrm{gr}$ dengan proporsi mencapai $63,16 \%$ dari total hasil tangkapan (Tabel 3). Pola pemanfaatan tersebut dapat menjadi ancaman bagi keberlanjutan jenis tersebut.

Tabel 2. Kisaran ukuran panjang karapas dan bobot lobster yang tertangkap di Teluk Sepi

Table 2. Size of carapas length and lobster weights of lobster that caught in Sepi Bay

\begin{tabular}{|c|c|c|c|c|c|c|}
\hline \multirow{2}{*}{$\begin{array}{c}\text { Kelas } \\
\text { Ukuran/ } \\
\text { Class } \\
\text { Size }\end{array}$} & \multicolumn{6}{|c|}{$\begin{array}{c}\text { Persentase bobot berdasarkan jenis / } \\
\text { Percentage of weights caught on based on species }\end{array}$} \\
\hline & $\begin{array}{l}\text { Batik } \\
\text { (P. Longipes, }(P .)\end{array}$ & $\begin{array}{l}\text { Batik Merah } \\
\text { I. femoristriga) }\end{array}$ & $\begin{array}{c}\text { Batu } \\
\text { (P.Penicilatus) }\end{array}$ & $\begin{array}{c}\text { Bambu } \\
\text { (P.versicolor) }\end{array}$ & $\begin{array}{l}\text { Mutiara } \\
\text { (P. ornatus) }\end{array}$ & $\begin{array}{c}\text { Pasir } \\
\text { (P. homarus) }\end{array}$ \\
\hline & & & & & & \\
\hline $200-300$ & 27,27 & & 3,4 & 0,0 & 100,00 & 0,00 \\
\hline$>300$ & 18,18 & 15,79 & 37,93 & 70,00 & 0,00 & 100,00 \\
\hline
\end{tabular}

\section{Kebiasaan Makanan}

Secara umum, berdasarkan 15 klasifikasi makanan fauna aquatik (BP2KSI, 2016), tampak jenis makanan lobster batik merah memenuhi tiga klasifikasi yakni moluska dengan kisaran 10-16,67\%, krustasea dengan kisaran 30-66,67\%, dan makrofita dengan kisaran $16,67-60 \%$ (Tabel 3). Perbedaan signifikan pada dominansi jenis makanan berdasarkan bulan pengamatan, dimana pada Mei didominasi oleh kelompok moluska dari famili gastropoda (siput siputan) mencapai 66,67\%, sedangkan pada Oktober didominasi krustasea dari kelompok kepiting.

Tabel 3. Indeks bagian terbesar makanan lobster batik merah

Table 3. Index of the largest food portion of red batik lobster

\begin{tabular}{|c|c|c|c|c|}
\hline \multirow[t]{2}{*}{$\begin{array}{c}\text { No/ } \\
\text { Number }\end{array}$} & \multirow{2}{*}{$\begin{array}{c}\text { Klasifikasi Jenis } \\
\text { Makanan/ } \\
\text { Classification of Food } \\
\text { Types }\end{array}$} & \multirow[t]{2}{*}{$\begin{array}{l}\text { Spesifikasi/ } \\
\text { Specification }\end{array}$} & \multicolumn{2}{|c|}{$\begin{array}{l}\text { Bulan pengamatan/ } \\
\text { Month of observation }\end{array}$} \\
\hline & & & Mei & Oktober \\
\hline 1 & Tumbuhan (Makrofita) & - & 16,67 & 10,00 \\
\hline \multirow[t]{2}{*}{2} & Moluska & Gastropoda (Siput siputan) & 66,67 & - \\
\hline & & Bivalvia (kekerangan) & - & 30,00 \\
\hline \multirow[t]{2}{*}{3} & Krustasea & Udang udangan & 16,67 & - \\
\hline & & kepiting & - & 60,00 \\
\hline
\end{tabular}




\section{Fekunditas}

Lobster batik merah di Perairan Teluk Sepi yang ditemukan dengan kondisi matang gonad adalah pada kisaran ukuran panjang karapas (CL) 3,8-4,7 cm dan bobot 66,12 - 106,45 gr. Kondisi pada saat obervasi, keseluruhan sampel tersebut tingkat kematangan ovarium yang ditemukan berada pada tahap III yang dikenal dengan istilah ripe, yakni ovarium berwarna terang ke merah dan dapat dipisahkan satuannya secara mikroskopis.

Fekunditas lobster batik merah yang ditemukan di perairan Teluk Sepi selama penelitian berada pada

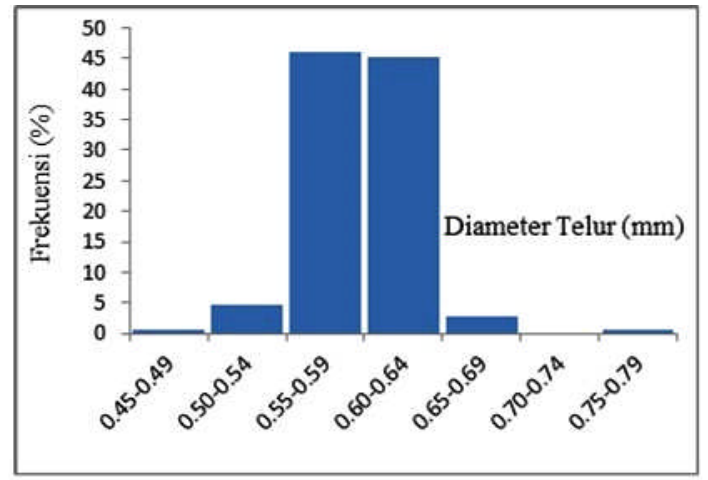

(a) TKG IV (Mei, 2016) kisaran antara $8.332-66.076$ butir dengan diameter telur berkisar antara 0,45-0,79 mm. Lobster betina pada tingkat kematangan gonad (TKG) III memiliki fekunditas sebesar 8.332-14.367 butir dengan diameter telur antara 0,20-0,38 mm, sedangkan lobster pada tingkat kematangan gonad TKG IV atau pada kategori spent, fekunditasnya berada pada kisaran 40.817 - 66.076 butir dengan diameter telur berkisar antara 0,45-0,79 mm. Berdasarkan sebaran diameter telur TKG IV yang siap memijah didapatkan satu modus diameter telur dimana pada Mei 2016 berada pada selang 0,55-0,59 $\mathrm{mm}$, sedangkan pada Oktober 2016 berada pada selang 0,6-0,64 mm (Gambar 6).

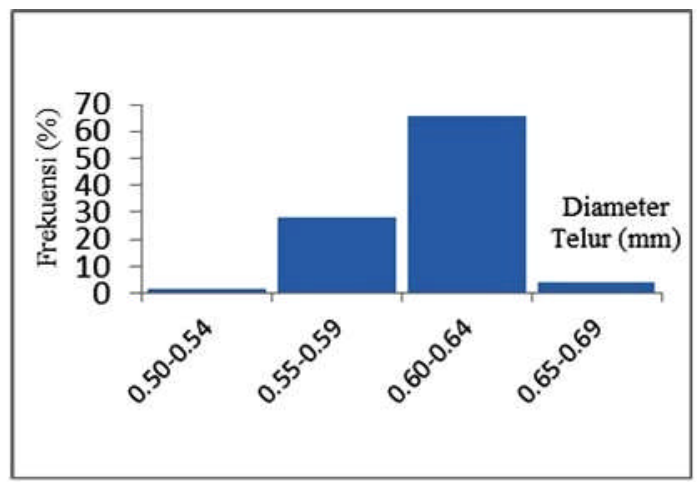

(b) TKG IV (Oktober, 2016)

Gambar 6. Diameter telur lobster batik merah (a) Mei 2016, (b) Oktober 2016.

Figure 6. Diameter of Red Batik Lobster eggs (a) May 2016, (b) October 2016.

\section{Keragaman Fisik Habitat Lobster}

Hasil analisis persentase tutupan karang di perairan Teluk Sepi (BP2KSI, 2016) dihasilkan persentase tertinggi yaitu dari kelompok coral sebesar $55,3 \%$ diikuti kelompok makro algae $(9,5 \%)$ dari 10 kategori/kelompok yang ditemukan (Tabel 4). Persentase nilai karang hidup yang direpresentasikan dalam kelompok coral memberikan gambaran bahwa kondisi terumbu karang di perairan Teluk Sepi tergolong baik (> 50\%) (Manuputy et al., 2009).

Tabel 4. Nilai persentase tutupan karang di perairan Teluk Sepi, Kab. Lombok Barat (Anonimous, 2016) Table 4. Percentage of coral cover age in Sepi Bay, Distric of West Lombok

\begin{tabular}{clc}
\hline No. & Kategori & Tutupan Karang (\%) \\
\hline 1. & Coral (C) & 55,3 \\
2. & Gorgonians (G) & 4,2 \\
3. & Sponges (S) & 2,1 \\
4. & Zoanthids (Z) & 0,0 \\
5. & Macroalgae (MA) & 9,5 \\
6. & Other Live (OL) & 6,4 \\
7. & Dead Coral With Algae (DCA) & 5,2 \\
\hline
\end{tabular}




\section{Bahasan \\ Sejarah dan Taksonomi}

Jenis lobster Panulirus longipes femoristriga tercatat baru ditemukan di 12 wilayah perairan yakni Indonesia, Jepang, Vietnam, Taiwan, Maldive, Australia, Polynesia, Kepulauan Golapagos (www.sealifebase.org), Mauritius, Zanzibar, La Reunion, Madagaskar, dan Tailand (Carpenter et al., 1998). Meskipun daerah penyebarannya sangat luas, yakni sepanjang Indo Pasifik Barat (Afrika Timur hingga Jepang, Kepulauan Fiji hingga Kepulauan Cook). Di Indonesia, lobster batik merah termasuk jenis yang jarang ditemukan. Dari seluruh kawasan perairan sentra lobster, sampai saat ini yang tercatat baru ditemukan di empat lokasi, yakni Perairan Sulawesi dan Papua Barat (Chan \& Chu, 1996; Wahyudin et al, 2016), Ambon (Holtuis, 1991; Chan \& Chu, 1996), serta pesisir Pulau Lombok (Kalih,
2012). Di perairan Lombok jenis ini tercatat ditemukan untuk kedua kalinya setelah 2012. Perairan Pulau Lombok merupakan perairan yang memiliki potensi penyebaran cukup melimpah untuk jenis ini (Kalih, 2012), meskipun tidak terlalu dikenal oleh komunitas pasar. Kurang dikenalnya jenis ini diduga karena kemiripan morfologi fisiknya dengan lobster batik, sehingga hampir seluruh pelaku usaha lobster mengkatagorikan jenis ini dalam kelompok lobster batik. Kondisi ini membuat jenis ini sulit terlacak sejauh mana komposisinya dalam komunitas lobster khususnya famili Palinuridae, genus Panulirus. Di lokasi penelitian, lobster ini dikenal dengan nama lokal lobster batik merah. Ciri morfologi fisik yang paling mudah untuk membedakan kedua jenis ini adalah pada jenis $P$. longipes terdapat lingkaran putih di setiap ruas kaki jalan, sedangkan pada jenis P.I. femoristriga berbentuk dua garis putih sejajar kaki jalan (George and Holtuis, 1965 in FAO, 1991).

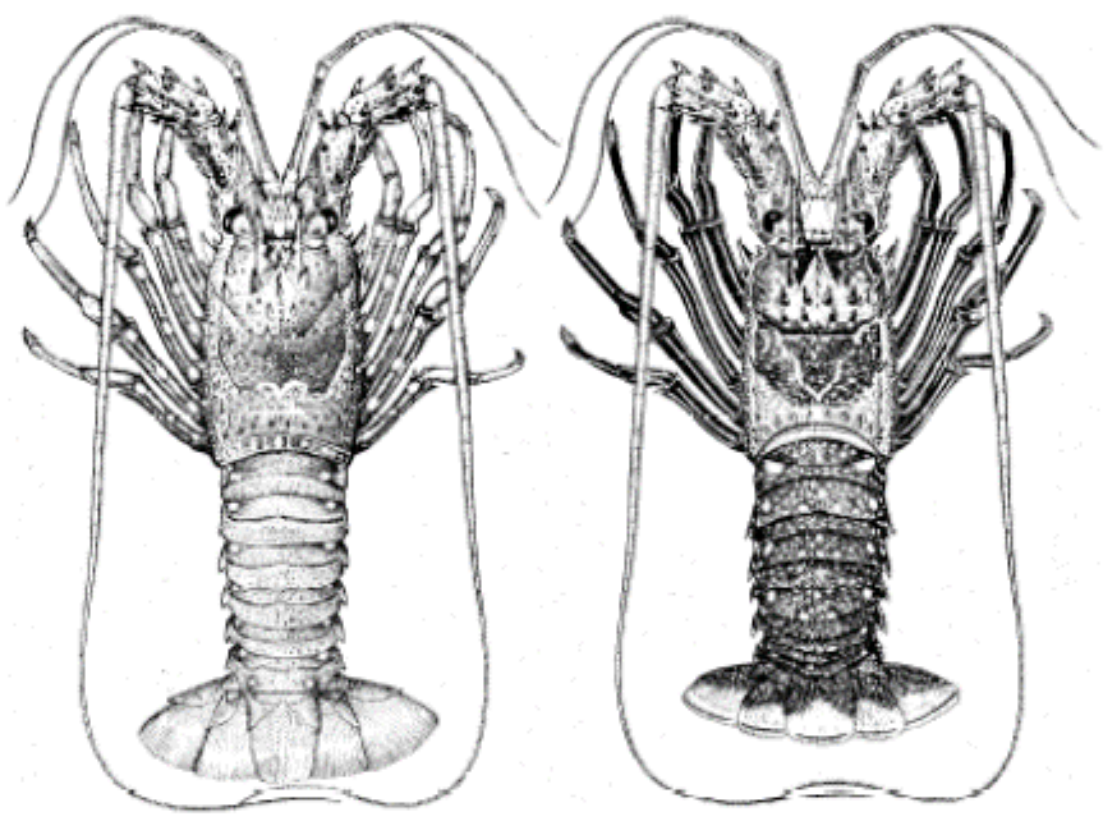

Gambar 7. Morfologi fisik antara (a) lobster batik ( $P$. longipes) dan (b) lobster batik merah ( $P$. I. f emoristriga) (George \& Holtuis, 1965 in FAO, 1991).

Figure 7. Physical morphology between (a) Lobster Batik (P. longipes) and (b) Lobster Batik Merah (P.l.femoristriga) (George \& Holtuis, 1965 in FAO, 1991).

\section{Sebaran Ukuran Panjang Karapas dan Bobot}

Sebaran ukuran lobster yang tertangkap, pada jenis ini maupun kelompok panulirus lainnya, umumnya didominasi oleh ukuran panjang karapas $<80 \mathrm{~mm}$ dan ukuran bobot $<200 \mathrm{gr}$ dengan proporsi mencapai 63,16\% dari total hasil tangkapan. Sebagian hasil tangkapan juga menunjukkan kondisi lobster yang sedang bertelur. Hal ini terjadi hampir di seluruh sentra lobster di beberapa perairan Indonesia, dimana dominasi hasil tangkapan berada pada ukuran larang tangkap yang disyaratkan dalam PermenKP 1/2015 dan dalam kondisi siap memijah (Nurfiarini et al., 2016). Pola pemanfaatan tersebut telah melanggar peraturan perundang undangan dan dapat menjadi ancaman bagi keberlanjutan sumberdaya lobster.

Karateristik perikanan lobster di Indonesia umumnya merupakan usaha perikanan skala kecil yang dikerjakan paruh waktu dan sangat dipengaruhi oleh cuaca. Meskipun secara ekonomi, nilai jual komoditas tergolong sangat tinggi, namun ketidakpastian hasil mendorong pelaku usaha sulit untuk mematuhi aturan yang melarang eksploitasi 
pada batas ukuran yang disayaratkan. Untuk menjaga kelestarian perikanan lobster, beberapa upaya pengelolaan yang dapat menjadi pilihan, diantaranya adalah: (i) implementasi sistem insentif, bagi nelayan yang menemukan lobster dalam kondisi bertelur; (ii) pengembangan kawasan perlindungan baik bagi puerulus maupun induk; dan (iii) peningkatan nilai tambah (value added) komoditas melalui upaya pembesaran, salah satunya dengan pengembangan sea ranching.

\section{Kebiasaan Makan dan Aspek Reproduksi}

Secara umum, kebiasaan makan pada beberapa lobster dari famili Palinuridae tercatat berupa moluska, crustacea, detritus dan echinodermata (Holthuis, 1991). Sementara hasil penelitian BK2KSI (2016) di Perairan Lombok menunjukkan bahwa jenis lobster batik umumnya lebih menyukai detritus dan moluska sebagai makanan utama, sedangkan krustacea dan makrofita sebagai makanan tambahan.

Pada aspek reproduksi, lobster batik merah pada kondisi TKG III masih akan mengalami proses pematangan menuju kondisi siap dikeluarkan (spent) yang diindikasikan dengan ditemukannya gonad masih dalam kondisi belum dapat dipisahkan antara telur dan jaringan gonadnya. Kondisi gonad TKG III masih terus tumbuh hingga tahap akan dikeluarkan (TKG IV) ataupun akan diserap kembali sebagian oleh tubuh lobster (atresia). Kondisi pada saat observasi, keseluruhan sampel yang diperoleh dengan tingkat kematangan ovarium berada pada tahap III yang dikenal dengan istilah ripe, yakni ovarium berwarna terang ke merah dan dapat dipisahkan satuannya secara mikroskopis (Berry, 1971). Perkembangbiakan spiny lobster belum dapat dipastikan pemijhannya (breeding) akan terjadi setelah berapa kali berganti kulit (Romimohtarto, 2009), namun pada beberapa penelitian menunjukkan bahwa tingkat matang pada telur untuk beberapa jenis seperti $P$. ornatus, terjadi pada tahun kedua pasca puerulus (fase juvenil) yakni ketika ukurannya $>1 \mathrm{~kg}$, sementara jenis $P$.homarus pada 12 bulan pasca puerulus atau ukuran panjang baku $\pm 15 \mathrm{~cm}$ dan ukuran panjang karapas untuk betina dan jantan masing masing $54 \mathrm{~mm}$ dan 50-60 $\mathrm{mm}$ (Subani et al., 1982). Kisaran fekunditas lobster batik merah dalam penelitian ini masih berada dibawah kisaran jenis lain dalam kelompok panulirus $(<100.000$ butir), dimana pada jenis pasir diketahui dapat mencapai kisaran 250.000-300.000 butir pada kisaran bobot induk antara 220-250 gr (Utami, 2009) bahkan hingga 460.000-4.000.000 butir (Moosa, 1984). Kondisi ini diduga bahwa jenis dan ukuran induk menentukan jumlah produksi telur.

\section{KESIMPULAN}

Lobster batik merah ( $P$. longipes femoristriga) merupakan salah satu sub varian dari lobster batik ( $P$. longipes) yang tercatat ditemukan kedua kali nya diperairan Lombok sebagai lokasi ke empat di Indonesia setelah Perairan Sulawesi, Papua Barat, dan Ambon. Komposisinya dalam komunitas tropical spiny lobster dari kelompok Palinuridae menempati komposisi bobot dan jumlah dalam kisaran 11,26$12,03 \%$ dan $21,28-22,5 \%$, berada di urutan ke empat setelah lobster batu, bambu dan batik. Struktur ukuran hasil tangkapan yang dipasarkan didominasi ukuran larang tangkap (<200 gr) yang mencapai $63,16 \%$. Jenis makanan utama dari kelompok moluska dari jenis gastropoda dan bivalvia, dan krustasea dari jenis udang udangan dan kepiting, serta makrofita. Fekunditas bekisar antara 8.332 - 66.076 butir dengan diameter telur berkisar antara 0,45-0,79 mm. Panjang karapas bobot pada saat pertamakali matang gonad masing-masing adalah $(3,8-4,7 \mathrm{~cm}),(4,3 \mathrm{~cm})$ dan $66,12-106,45 \mathrm{gr}$ (rata rata $87,58 \mathrm{gr}$ ).

\section{PERSANTUNAN}

Tulisan ini merupakan bagian dari penelitian Pengembangan Kawasan Konservasi di Lombok Tengah dah Lombok Barat, APBNP 2016 pada Balai Penelitian Pemulihan dan Konservasi Sumberdaya Ikan. Ucapan terimakasih ditujukan kepada Bapak Rahmat Sarbini dan Yusuf Nugraha selaku teknisi lapangan yang telah membantu dalam pengumpulan dan pencatatan data di lapangan.

\section{DAFTAR PUSTAKA}

Bagenal, T. B., \& Braum, E. (1978). Eggs and early life history. In Bagenal, T. (ed.). Methods for Assessment of Fish Production in Freshwaters (pp.165-201). Blackwell Publishing Ltd, Oxford, England.

Anonimous. (2016). Penelitian pengembangan kawasan konservasi perikanan di Lombok Tengah Nusa Tenggara Barat. Laporan Hasil Penelitian (tidak dipublikasikan). Balai Penelitian dan Konservasi Sumberdaya Ikan.

Carpenter, K.E., \& Neim, V.H. (1998). Species identification guide for fieheries purposes: the living marine resources of the western central pacific, Vol. 2. Chephalopoda, crustaceans, holothurians and Sharks. FAO, Rome. 687-1396. 
Chan, T. Y., Ma K. Y., \& Chu, K.H. (2013). The deepsea spiny lobster genus Puerulus Ortmann, 1897 (Crustacea, Decapoda, Palinuridae), with descriptions of five new species In Ahyong S.T., Chan T.Y., Ng P.K.L (Eds) Tropical Deep-Sea Benthos. Muséum national d'Histoire naturelle, 27,191-230.

Chan, T.Y, \& Chu, K.H. (1996). On the different forms of Panulirus longipes femoristriga (Von Morten, 1872) (Crustacea: Decapoda: Palinuridae), with description of a new species. Journal of Natural History, London. 30: 367-387 p.

Chan, T.Y, \& Nge, P.K.L. (2001). On the nomenclature of thecommercially important spiny lobsters Panulirus longipes femoristriga (Von Martens, 1872), P. bispinosus Borradaile, 1899, and $P$. Albiflagellum

Chan , T.Y, \& Chu, K.H. (1996). (Decapoda, Palinuridae). Crustaceana 74:123-127 p.

Chan, T.Y. (1998). Lobster. In: Carpenter KE, Niem VH (Eds) FAO Species Identification Guide for Fishery Purposes. The Living Marine Resources of the Western Central Pacific. FAO, Rome. 2, 687-1396 p.

Chow, S., Yamada, H. \& Suzuki, N. (2006). Identification of mid- to final stage phyllosoma larvae of the genus Panulirus white, 1847 collected in the Ryukyu Archipelago. Crustaceana 79 (6), 745-764.

Direktorat Jenderal Perikanan Tangkap. (2015). Statistik Perikanan Tangkap di Laut Menurut Wilayah Pengelolaan Perikanan Negara Republik Indonesia (WPP-NRI) 2005-2014. Jakarta. 966 hlm

Effendie, M.I. (1979). Metode Biologi Perikanan (p. 112). Yayasan Dewi Sri, Bogor.

FAO. (1991). FAO species catalogue, marine lobsters of the World. FAO Fisheries Synopsis, No. 125, Vol 13 (145 p). Rome.

Holthuis, L.B. (1991). FAO species catalogue. 13. Marine lobsters of the world. An annotated and illustrated catalogue of species of interest to fisheries known to date. FAO Fisheries Synopsis. No. 125, Vol. 13. Rome, FAO.292 p.

http://www.sealifebase.org/Country/ CountryList.php?D=21095\&GenusName=Panulirus\&Species Name=femoristriga.
Kalih, L.A.T.T.W.S. (2012). Keragaman serta distribusi lobster anggota palinuridae dan scyllaridae di perairan pantai Pulau Lombok. Thesis Program Pasca Sarjana Program Studi Biologi Fakultas Biologi Universitas Gadjah Mada (tidak dipublikasikan). Yogyakarta.

Lavery, S.D., Farhadi A, Farahmand H, Chan T-Y, Azhdehakoshpour A, Thakur V., \& Jeffs, A.G. (2014). Evolutionary divergence of geographic subspecies within the scalloped spiny lobster Panulirus homarus (Linnaeus 1758). PLOS ONE 9(6): e97247. doi:10.1371/journal.

Milne, E. A. (1868). Observations sur la faune carcinologique des îles du Cap-Vert. Nouvelles Archives Museum Histoire naturelle, Paris, 4: 4968, pls. $16-18 p$

Moosa, M.K. \& Indra, A. (1984). Udang karang (Panulirus spp) dari Perairan Indonesia. Proyek Studi Potensi Sumber Daya Alam Indonesia. Studi Potensi Sumber Hayati Ikan. LON-LIPI, Jakarta

Natarajan, A. V. \& Jhingran, A. G. (1961). Index of preponderance-a method of grading the food elements in the stomach analysis of fishes. Indian Journal of Fisheries. 8 (1), 54-59.

Nurfiarini. A., Wijaya. D., Mujiyanto, Satria, F. \& Kartamihardja, E.S. (2016). Pendekatan sosial ekologi untuk penilaian kesesuaian lokasi restoking lobster pasir (Panulirus homarus Linnaeus, 1758) pada beberapa perairan di Indonesia. J. Lit. Perikan. Ind. 22(2), 123-138.

Phillips, B.F. (Ed.). (2006). Lobsters: biology, management, aquaculture, and fisheries (p. 506). Blackwell Publishing Ltd., Singapore.

Ravago, R.G. \& Juinio-Meñez, M.A. (2002). Phylogenetic position of the striped-legged forms of Panulirus longipes (A. Milne-Edwards, 1868) (Decapoda, Palinuridae) Inferred from Mitochondrial DNA Sequences. Crustaceana. 75(9), 1047-1059.

Romimohtarto, K. \& Juwana, S. (2009). Biologi laut: ilmu pengetahuan tentang biota laut. Edisi revisi (p 540). Cetakan keempat. Penerbit Djambatan, Jakarta.

Tewfik A., Mills D., \& Adhuri, D. (2009). Spiny lobster resources and opportunity for culture in posttsunami Aceh, Indonesia. In Williams K.C. (ed.) 2009. Spiny lobster aquaculture in the Asia-Pacific 
region. Proceedings of an international symposium held at Nha Trang, Vietnam, 9-10 December 2008. ACIAR Proceedings No. 132. Australian Centre for International Agricultural Research: Canberra. $162 \mathrm{p}$.

Utami, D.D.Y. (2009). Analisis sumberdaya dan tingkat pemanfaatan lobster (Panulirus $s p$.) yang didaratkan di Pangandaran, Ciamis, Jawa Barat. Fakultas Perikanan dan Kelautan, Institut Pertanian Bogor. Thesis Pascasarjana (Tidak dipublikasikan). Bogor.

Wahyudin R.A., Hakim A.A., Boer M., Fajaralllah A., \& Wardiatno, Y. (2016). New records of Panulirus femoristriga Von Morten, 1872 (Crustacea Achelata Palinuridae) from Celebes and Seram Island, Indonesia. Biodiversity Journal 7 (4), 901-906

Wardiatno Y., Hakim A.A., Mashar A., Butet N.A., Adrianto, L., \& Farajallah A. (2016). First record of Puerulus mesodontus Chan, Ma \& Chu, 2013 (Crustacea, Decapoda, Achelata,Palinuridae) from south of Java, Indonesia. Biodiversity Data Journal, 4: e8069.

Williams, A.B. (1986). Lobsters - identification, world distribution, and U.S. trade. Marine Fisheries Review, 48(2), 1-36, figs 1-80. 
Lampiran 1. Sebaran ukuran panjang karapas (cm), bobot (gram) serta Tingkat Kematangan Gonad Lobster Batik Merah yang ditemukan pada Mei dan Oktober di Teluk Sepi

Appendix 1. Distribution of length of carapace (cm), weight (gram) and Gonad Maturity Level of Red Batik Lobster found in May and October in Sepi Bay.

\begin{tabular}{|c|c|c|c|c|c|c|}
\hline $\begin{array}{l}\text { Nama lokal/ } \\
\text { Local name }\end{array}$ & $\begin{array}{c}\text { Bulan } \\
\text { Pengamatan/ } \\
\text { Month of } \\
\text { Observation }\end{array}$ & $\begin{array}{c}\text { Panjang } \\
\text { Karapas/ } \\
\text { Carapac } \\
\text { Length } \\
(\mathrm{cm})\end{array}$ & $\begin{array}{l}\text { Berat / } \\
\text { Weight } \\
\text { (gr) }\end{array}$ & $\begin{array}{l}\text { Jenis } \\
\text { Kelamin/ } \\
\text { Gender }\end{array}$ & $\begin{array}{l}\text { TKG/ } \\
\text { level of } \\
\text { gonad } \\
\text { maturity }\end{array}$ & $\begin{array}{l}\text { Keterangan/ } \\
\text { Explanation }\end{array}$ \\
\hline Lobster Batik & & & & & & \multirow{13}{*}{$\begin{array}{l}\text { Bertelur, dengan } \\
\text { posisi telur suda } \\
\text { diluar dan } \\
\text { menempel } \\
\text { Bertelur, dengan } \\
\text { posisi telur suda } \\
\text { diluar dan } \\
\text { menempel }\end{array}$} \\
\hline $\begin{array}{l}\text { Merah } \\
\text { Lobster Batik }\end{array}$ & Mei & 5,55 & 178,59 & $J$ & III & \\
\hline $\begin{array}{l}\text { Merah } \\
\text { Lobster Batik }\end{array}$ & Mei & 4,8 & 113,96 & $J$ & II & \\
\hline $\begin{array}{l}\text { Merah } \\
\text { Lobster Batik }\end{array}$ & Mei & 4,65 & 101,92 & $\mathrm{~J}$ & II & \\
\hline Lobster Batik & Mei & 3,8 & 66,12 & B & III & \\
\hline Lobster Batik & Mei & 4,4 & 118,65 & B & IV & \\
\hline $\begin{array}{l}\text { Merah } \\
\text { Lobster Batik }\end{array}$ & September & 5,2 & 161,2 & b & IV & \\
\hline $\begin{array}{l}\text { Merah } \\
\text { Lobster Batik }\end{array}$ & September & 5,1 & 128,46 & j & II & \\
\hline $\begin{array}{l}\text { Merah } \\
\text { Lobster Batik }\end{array}$ & September & 5,2 & 136,2 & j & III & \\
\hline $\begin{array}{l}\text { Merah } \\
\text { Lobster Batik }\end{array}$ & September & 5 & 120,23 & j & 1 & \\
\hline $\begin{array}{l}\text { Merah } \\
\text { Lobster Batik }\end{array}$ & September & 5,9 & 170,21 & j & II & \\
\hline $\begin{array}{l}\text { Merah } \\
\text { Lobster Batik }\end{array}$ & September & 4,7 & 106,45 & $b$ & - & \\
\hline Merah & September & 4,4 & 40,17 & $b$ & - & \\
\hline
\end{tabular}

